\title{
Protocol
}

\section{SELEX to Identify Protein-Binding Sites on RNA}

James L. Manley

\section{MATERIALS}

SELEX (systematic evolution of ligands by exponential enrichment) is a very powerful method for determining the binding site of a protein on RNA. It relies on the ability of an RNA-binding protein to select high-affinity RNA ligands from a randomized pool of RNAs. SELEX experiments are performed over several "rounds," with each round resulting in increased enrichment of RNAs capable of binding to the protein. There are many variations of SELEX strategies, but they all rely on the ability to separate bound RNA from unbound RNA. The method presented here uses tagged proteins; however, it is also possible to use other separation techniques (e.g., filter binding or antibodies).

It is essential that you consult the appropriate Material Safety Data Sheets and your institution's Environmental Health and Safety Office for proper handling of equipment and hazardous materials used in this protocol.

RECIPES: Please see the end of this article for recipes indicated by $<R>$. Additional recipes can be found online at http://cshprotocols.cshlp.org/site/recipes.

Reagents

ATP, CTP, GTP, UTP (100 mм each)

BamHI $(200 \mu \mathrm{L})$

DNase I (RNase-free; 2 units/ $\mu \mathrm{L})$

dNTP mix (10 mm each of dATP, dCTP, dGTP, dTTP)

Ethanol $(70 \%, 100 \%)$

Klenow buffer $(5 \times)<\mathrm{R}>$

Klenow enzyme

NT2 buffer $<$ R $>$

Phenol:chloroform:isoamyl alcohol (PCA) (25:24:1)

Primers:

- "Forward" primer sequence: 5'-CGCGAATTCTAATACGACTCACTATAGGGGCCACC AACGACATT-3'

The forward primer must contain a $T 7$ promoter sequence and a restriction enzyme site for cloning. Here, the ECoRI restriction site is nucleotides 4-9, and the T7 promoter is nucleotides 10-29.

Adapted from RNA: A Laboratory Manual, by Donald C. Rio, Manuel Ares Jr, Gregory J. Hannon, and Timothy W. Nilsen. CSHL Press, Cold Spring Harbor, NY, USA, 2011.

(C) 2013 Cold Spring Harbor Laboratory Press

Cite this article as Cold Spring Harb Protoc; 2013; doi:10.1101/pdb.prot072934 
- "Reverse" primer sequence: 5'-CCCGACACCGCGGGATCCATGGGCACTATTTATA TCAA-3'

The reverse primer must contain a restriction enzyme site for cloning and hybridization sequence for reverse transcription. Here, the BamHI restriction site is nucleotides 13-18.

- "Library" primer sequence: 5'-TTACAGCAACCACCGGGGATCCATGGGCACTATTT ATATCAAC $(\mathrm{N})_{25}$ AATGTCGTTGGTGGCCC-3'

The library primer must contain a region of randomized sequence as well as sequences that anneal to the forward and reverse primers.

Proteinase K (10 mg/mL)

Proteinase K buffer for SELEX $(2 \times)<\mathrm{R}>$

Protein of interest fused to a tag for purification (such as GST or histidine)

Reverse transcriptase (M-MuLV 200 units/ $\mu \mathrm{L}$ )

Reverse transcriptase buffer for SELEX $(10 \times)<\mathrm{R}>$

RNase inhibitor (40 units/ $\mu \mathrm{L}$ )

SDS extraction buffer $<\mathrm{R}>$

Sepharose or agarose beads for purification of complexes

Sodium acetate ( $3 \mathrm{M}, \mathrm{pH} 5.2$ )

T7 RNA polymerase

T7 transcription buffer $(10 \times)<\mathrm{R}>$

Taq DNA polymerase ( 1 unit/ $\mu \mathrm{L})$ and buffer

Polyacrylamide gel (15\%; 19:1 acrylamide:bis-acrylamide) containing $8 \mathrm{~m}$ urea, prepared in $1 \times \mathrm{TBE}$ Polyacrylamide gel (15\%; 19:1 acrylamide:bis-acrylamide), prepared in 1× TBE

TE buffer ( $\mathrm{pH}$ 8.0)

Vector for cloning and bacteria for transformation (see Step 46)

Yeast tRNA $(10 \mathrm{mg} / \mathrm{mL})$

Equipment

Beaker with $50 \mathrm{~mL}$ of $\mathrm{H}_{2} \mathrm{O}$ at $75^{\circ} \mathrm{C}$

Conical centrifuge tube $(15 \mathrm{~mL})$

Dry ice

Ice

Microcentrifuge

Microcentrifuge tubes $(1.5 \mathrm{~mL})$

PCR tubes

Polypropylene tubes (12 mL)

Shaker

Spectrophotometer

Thermal cycler

Tube rocker

Ultraviolet (UV) light source (254 nm, handheld)

Vortex mixer

Water baths $\left(37^{\circ} \mathrm{C}, 42^{\circ} \mathrm{C}, 55^{\circ} \mathrm{C}\right.$, and $\left.75^{\circ} \mathrm{C}\right)$

$\mathrm{X}$-ray intensifying screen for UV shadowing 
J.L. Manley

METHOD

Convert Library of Oligonucleotides into Double-Stranded DNA Transcription Templates

Before beginning this protocol, it is necessary to understand the experimental flow (see Fig. 1).

1. Anneal the "forward" and "library" primers by mixing the following in a 1.5-mL tube:

$\begin{array}{lr}\text { Klenow buffer }(5 \times) & 200 \mu \mathrm{L} \\ 100 \mu \mathrm{M} \text { "forward" primer } & 85 \mu \mathrm{L} \\ 100 \mu \mathrm{M} \text { "library" primer } & 85 \mu \mathrm{L} \\ \mathrm{H}_{2} \mathrm{O} & 590 \mu \mathrm{L}\end{array}$

2. Heat the mixture for $15 \mathrm{~min}$ to $75^{\circ} \mathrm{C}$ and then transfer it to a beaker containing $50 \mathrm{~mL}$ of $\mathrm{H}_{2} \mathrm{O}$ at $75^{\circ} \mathrm{C}$. Allow the tube to cool slowly to room temperature. Centrifuge briefly for $5 \mathrm{sec}$ at room temperature.

3. Extend the annealed primers by adding $20 \mu \mathrm{L}$ of dNTP mix (10 mM each of dATP, dCTP, dGTP, and dTTP) and $20 \mu \mathrm{L}$ of Klenow enzyme. Incubate for $1 \mathrm{~h}$ at $37^{\circ} \mathrm{C}$.

4. Add $100 \mu \mathrm{L}$ of $3 \mathrm{~m}$ sodium acetate ( $\mathrm{pH}$ 5.2).

5. Divide the sample into four $275-\mu \mathrm{L}$ aliquots and add $600 \mu \mathrm{L}$ of $100 \%$ ethanol to each.

6. Freeze on dry ice for $10 \mathrm{~min}$ and then centrifuge at $\geq 12,000 \mathrm{~g}$ for $15 \mathrm{~min}$ at room temperature.

7. Decant the supernatant and wash the pellet with $70 \%$ ethanol. Centrifuge at $\geq 12,000 \mathrm{~g}$ for 5 min at room temperature. Decant the supernatant and air-dry the pellet.

1. Convert library of oligonucleotides into double-stranded DNA transcription templates

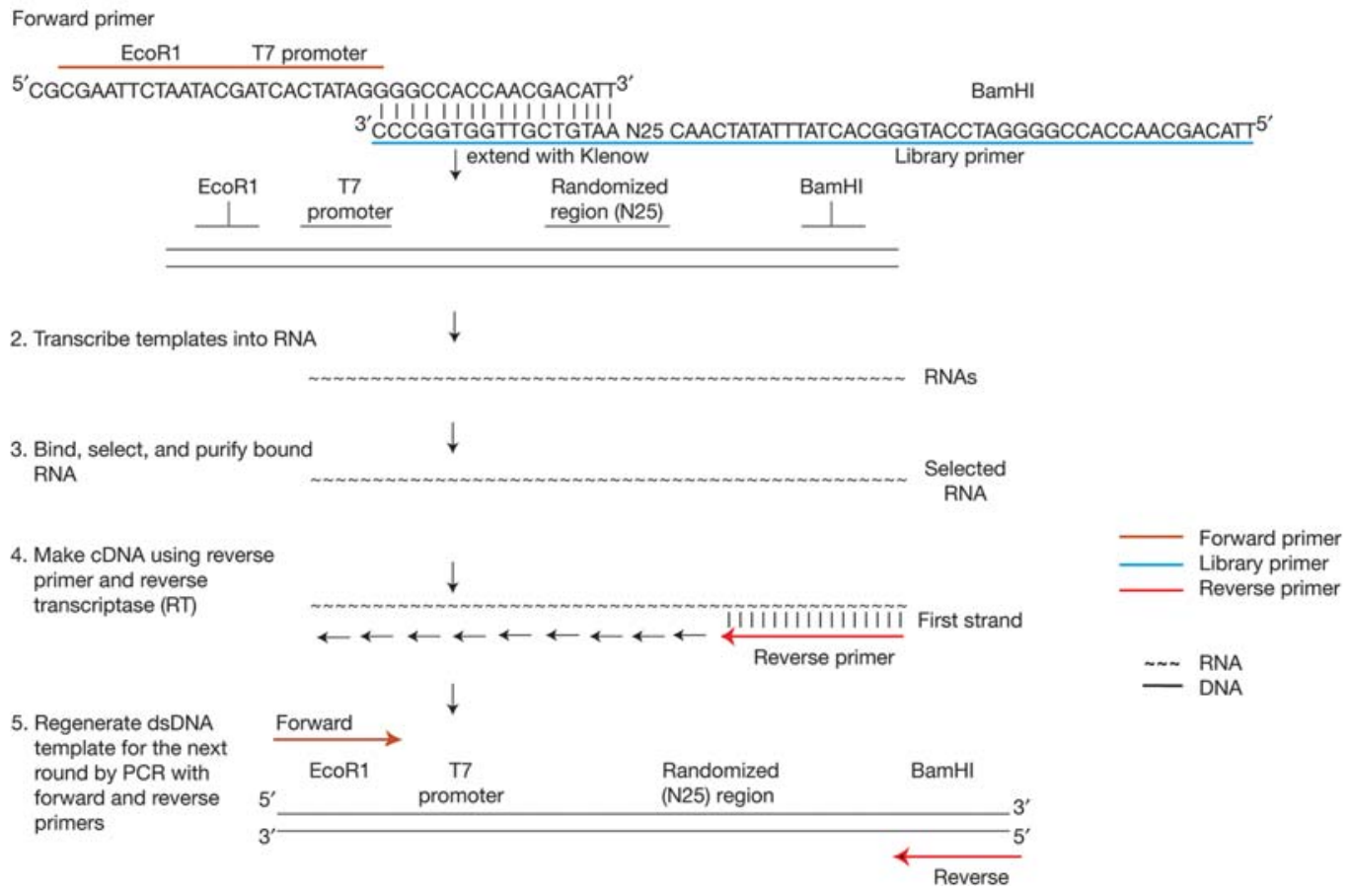

FIGURE 1. Schematic representation of a "round" of SELEX. Each "round" of SELEX consists of the same sequence of steps. First, it is necessary to construct DNA templates for synthesizing the randomized RNA pool. The pool is then synthesized, labeled, and allowed to bind to the protein of interest. Bound RNAs are then converted back into DNA templates by RT-PCR. This process is reiterated until the bulk ( $\geq 90 \%)$ of the pool is capable of binding to the protein. At this point, the "final" pool is converted back to double-stranded DNA, cloned, and sequenced. 
8. Resuspend the double-stranded DNA library from Step 7 and gel-purify using a $15 \%$ nondenaturing TBE polyacrylamide (19:1 acrylamide:bis-acrylamide) gel. Electrophorese until the xylene cyanol dye is close to the bottom of a $15-\mathrm{cm}$-long gel.

9. Visualize the nucleic acids by UV shadowing.

10. Excise the band containing the full-length double-stranded library. Crush the excised gel band and elute the DNA using 1-2 $\mathrm{mL}$ of $0.5 \mathrm{~m}$ sodium acetate overnight with shaking.

11. Collect supernatant, precipitate the DNA with ethanol, and wash the precipitate with $70 \%$ ethanol. Repeat the elution once to increase recovery if desired.

12. Dissolve the DNA in $\sim 100 \mu \mathrm{L}$ of TE buffer ( $\mathrm{pH} 8.0$ ).

13. Determine the $\mathrm{OD}_{260}$ and convert the value to molar concentration. For example, for $50 \mu \mathrm{g} / \mathrm{mL}$ per $\mathrm{OD}_{260}$, the 95-nucleotide product has a molecular weight of 62,440 $\mathrm{g} / \mathrm{mol}$.

14. Dilute the DNA to $1.7 \mathrm{nmol} / 100 \mu \mathrm{L}$ and divide it into $100-\mu \mathrm{L}$ aliquots.

Transcribe the Double-Stranded DNA Template for First Round

15. Set up the transcription reaction in a $15-\mathrm{mL}$ conical centrifuge tube as follows:

$\begin{array}{lr}\text { 1.7-nmol double-stranded DNA library (from Step 14) } & 100 \mu \mathrm{L} \\ \text { 10× T7 transcription buffer } & 1 \mathrm{~mL} \\ 100 \mathrm{mM} \text { ATP } & 100 \mu \mathrm{L} \\ 100 \mathrm{mM} \text { CTP } & 100 \mu \mathrm{L} \\ 100 \mathrm{mM} \text { GTP } & 100 \mu \mathrm{L} \\ 100 \mathrm{mM} \text { UTP } & 100 \mu \mathrm{L} \\ \text { T7 RNA polymerase } & 1 \mathrm{~mL} \\ \mathrm{H}_{2} \mathrm{O} & 7.5 \mathrm{~mL}\end{array}$

16. Mix the reagents gently by inverting and then incubate for $2 \mathrm{~h}$ at $37^{\circ} \mathrm{C}$.

The solution should become cloudy.

17. Add $100 \mu \mathrm{L}$ of RNase-free DNase I to the transcription reaction and incubate for a further 15 $\min$ at $37^{\circ} \mathrm{C}$.

18. Split into $2.5-\mathrm{mL}$ aliquots in $12-\mathrm{mL}$ polypropylene tubes and precipitate the RNA with ethanol.

19. Purify the full-length RNA transcripts on an $8 \mathrm{~m}$ urea, 15\% polyacrylamide gel.

20. Visualize the nucleic acids by UV shadowing.

21. Excise the band containing full-length RNA transcripts. Elute RNA overnight as in Step 10. Collect the supernatant, precipitate with ethanol, and wash the precipitate with $70 \%$ ethanol.

22. Dissolve the RNA in $\sim 100 \mu \mathrm{L}$ of TE buffer (pH 8.0) or in SDS extraction buffer.

23. Determine the $\mathrm{OD}_{260}$ and convert the value to molar concentration.

For example, for $40 \mu \mathrm{g} / \mathrm{mL}$ per $O D_{260}$, the 69-nucleotide, single-stranded RNA has a molecular weight of $23,630 \mathrm{~g} / \mathrm{mol}$.

24. Dilute the RNA to $17 \mathrm{nmol} / 100 \mu \mathrm{L}$ and store in $100-\mu \mathrm{L}$ aliquots at $-80^{\circ} \mathrm{C}$.

Each aliquot on average contains 10 RNA copies of each of the $1 \times 10^{15}$ DNA templates.

Protein-RNA Binding and Selection

25. Select RNA from Step 24 using a matrix bound to the protein of interest (e.g., glutathioneSepharose beads with a GST-tagged protein or Ni-NTA agarose with a histidine-tagged protein).

Immunoprecipitation, filter binding, or a mobility shift assay can also be used to separate protein-RNA complexes from free $R N A$. 
26. Prepare sufficient beads for $2 \mathrm{mg}$ of each protein of interest and an equal volume of beads to preclear the RNA library. Wash the beads in NT2 buffer.

27. Bind $1-10 \mu \mathrm{g}$ of protein to Sepharose or agarose beads for at least $2 \mathrm{~h}$ at $4^{\circ} \mathrm{C}$ with rocking.

28. Pellet the beads by centrifugation at $8000 \mathrm{~g}$ for $10 \mathrm{sec}$ at room temperature. Then, wash the beads three times with $1 \mathrm{~mL}$ of NT2 buffer each time.

29. Preclear a 17-nmol aliquot of the RNA library from Step 24 by binding it to beads for $30 \mathrm{~min}$ at $4^{\circ} \mathrm{C}$. Pellet the beads by centrifugation at $8000 \mathrm{~g}$ for $10 \mathrm{sec}$ at room temperature. Keep the supernatant, which contains the precleared RNA library.

30. Bind the precleared RNA library from Step 29 to the proteins from Step 28 by incubating for at least $2 \mathrm{~h}$ at $4^{\circ} \mathrm{C}$ with rocking.

31. Wash the beads five times with $1 \mathrm{~mL}$ of NT2 buffer each time. After the last wash, leave $100 \mu \mathrm{L}$ of NT2 buffer on the beads.

32. Add $100 \mu \mathrm{L}$ of $\mathrm{H}_{2} \mathrm{O}, 200 \mu \mathrm{L}$ of $2 \times$ proteinase $\mathrm{K}$ buffer for SELEX, and $5 \mu \mathrm{L}$ of proteinase K. Incubate for $15 \mathrm{~min}$ at $37^{\circ} \mathrm{C}$.

33. Add $400 \mu \mathrm{L}$ of PCA (25:24:1), vortex for $30 \mathrm{sec}$, and then centrifuge at 12,000 $\mathrm{g}$ for $1 \mathrm{~min}$ at room temperature.

34. Transfer aqueous layer, which contains the RNA, to a clean tube. Add $2 \mu \mathrm{L}$ of $10 \mathrm{mg} / \mathrm{mL}$ of yeast tRNA, $40 \mu \mathrm{L}$ of $3 \mathrm{~m}$ sodium acetate ( $\mathrm{pH} 5.2$ ), and $1 \mathrm{~mL}$ of $100 \%$ ethanol. Mix thoroughly, freeze on dry ice for $10 \mathrm{~min}$, and then centrifuge at $\geq 12,000 \mathrm{~g}$ for $15 \mathrm{~min}$ at room temperature.

35. Decant the supernatant, wash the RNA pellet with $70 \%$ ethanol, and centrifuge at $\geq 12,000 \mathrm{~g}$ for $5 \mathrm{~min}$ at room temperature. Decant the supernatant and air-dry the pellet.

\section{Reverse Transcription PCR}

36. Resuspend the RNA pellet from Step 35 in $13 \mu \mathrm{L}$ of $\mathrm{H}_{2} \mathrm{O}$. Add the following:

$\begin{array}{lr}\text { "Reverse" primer } & 3 \mu \mathrm{L} \\ \text { Reverse transcriptase buffer for SELEX (10×) } & 2 \mu \mathrm{L} \\ \text { dNTP mix } & 2 \mu \mathrm{L} \\ \text { Reverse transcriptase } & 0.5 \mu \mathrm{L}\end{array}$

Incubate the reaction for $5 \mathrm{~min}$ at $55^{\circ} \mathrm{C}$ and then for $1 \mathrm{~h}$ at $42^{\circ} \mathrm{C}$.

37. Transfer $6 \mu \mathrm{L}$ from the reverse transcription reaction into a PCR tube and add the following:

$\begin{array}{lr}\mathrm{H}_{2} \mathrm{O} & 75.5 \mu \mathrm{L} \\ \text { Taq buffer }(10 \times) & 10 \mu \mathrm{L} \\ \text { dNTP mix } & 2 \mu \mathrm{L} \\ \text { "Forward" primer } & 3 \mu \mathrm{L} \\ \text { "Reverse" primer } & 3 \mu \mathrm{L} \\ \text { Taq polymerase } & 0.5 \mu \mathrm{L}\end{array}$

38. Denature for $5 \mathrm{~min}$ at $94^{\circ} \mathrm{C}$. Then, amplify for 25 cycles of $30 \mathrm{sec}$ at $94^{\circ} \mathrm{C}, 30 \mathrm{sec}$ at $50^{\circ} \mathrm{C}$, and $30 \mathrm{sec}$ at $72^{\circ} \mathrm{C}$ followed by a final extension of $10 \mathrm{~min}$ at $72^{\circ} \mathrm{C}$.

39. Add $1 \mu \mathrm{L}$ of BamHI to the reaction and incubate at $37^{\circ} \mathrm{C}$ to regenerate the $3^{\prime}$ ends of original library.

40. Extract with an equal volume of PCA. Precipitate the double-stranded DNA template with ethanol, air-dry the pellet, and resuspend it in $15 \mu \mathrm{L}$ of $\mathrm{H}_{2} \mathrm{O}$. 
Transcribe Double-Stranded DNA for Subsequent Rounds

41. Combine the following:

T7 transcription buffer $(10 \times)$

NTP mix (2.5 mm each ATP, CTP, UTP, GTP)

Double-stranded DNA template (from RT-PCR

of previous round [Step 40])

RNase inhibitor (40 units/ $\mu \mathrm{L}$ )

$\mathrm{H}_{2} \mathrm{O}$

T7 RNA polymerase

Incubate for $1 \mathrm{~h}$ at $37^{\circ} \mathrm{C}$.
$2 \mu \mathrm{L}$

$8 \mu \mathrm{L}$

$3 \mu \mathrm{L}$

$1 \mu \mathrm{L}$

$4 \mu \mathrm{L}$

$2 \mu \mathrm{L}$

42. Add $1.5 \mu \mathrm{L}$ of RNase-free DNase I to the reaction and incubate for an additional $10 \mathrm{~min}$ at $37^{\circ} \mathrm{C}$.

43. Add $78.5 \mu \mathrm{L}$ of $\mathrm{H}_{2} \mathrm{O}$ and $10 \mu \mathrm{L}$ of $3 \mathrm{~m}$ sodium acetate ( $\mathrm{pH}$ 5.2). Extract the reaction with an equal volume of PCA, precipitate with ethanol, air-dry the RNA pellet, and then resuspend RNA in $20 \mu \mathrm{L}$ of $\mathrm{H}_{2} \mathrm{O}$.

44. Use one-quarter $(5 \mu \mathrm{L})$ of the RNA from Step 43 to repeat the cycle for the binding to proteinRNA-binding step (Steps 25-35). Repeat the RT-PCR (Steps 36-40). Usually 4-10 cycles of enrichment are required.

45. Check for protein-RNA binding by electrophoretic mobility shift assay using radiolabeled RNA (either by incorporation of radioactive nucleotide during transcription or by endlabeling RNA transcripts) and the purified protein of interest.

\section{Determine the Sequence Recognized by the Protein}

46. After sufficient enrichment has been achieved ( $\geq 90 \%$ of the transcribed RNA is bound by the protein), clone the double-stranded DNA templates into a suitable vector and transform bacteria.

47. Pick a large number (50-100) of transformants and determine the nucleotide sequence of the inserts.

SELEX (Kenan and Keene 1999; Bouvet 2001) is extremely useful for determining preferred RNAbinding sites for specific RNA-binding proteins. Consensus sequences for binding sites should emerge from the analysis. It is often the case that suboptimal (but functional) sequence elements can be determined if the cloning and sequencing are performed at earlier "rounds" of selection. In general, the number of iterative selection rounds required is determined by the size of the starting pool (e.g., RNA containing seven randomized positions contains only $\sim 16,000$ individual molecules, whereas an RNA randomized at 10 positions has a pool size of $\sim 10^{6}$ individual molecules) and the stringency of selection. To ensure adequate coverage, it is important that $\sim 10$ times the theoretical pool size be synthesized for each reaction. It is essential that the investigator know and keep in mind the number of distinct molecules required for adequate representation of the pool and take steps to ensure that each molecule of distinct sequence is present in the starting pool. 
J.L. Manley

\section{RECIPES}

Klenow Buffer (5×)

\begin{tabular}{lcr} 
Reagent & $\begin{array}{c}\text { Quantity } \\
\text { (for } 1 \mathrm{~mL})\end{array}$ & $\begin{array}{c}\text { Final } \\
\text { concentration }\end{array}$ \\
\hline $\mathrm{NaCl}(5 \mathrm{M})$ & $50 \mu \mathrm{L}$ & $250 \mathrm{~mm}$ \\
Tris- $\mathrm{HCl}(1 \mathrm{M}, \mathrm{pH} 7.9)$ & $50 \mu \mathrm{L}$ & $50 \mathrm{~mm}$ \\
DTT (dithiothreitol; $1 \mathrm{M})$ & $5 \mu \mathrm{L}$ & $5 \mathrm{~mm}$ \\
$\mathrm{H}_{2} \mathrm{O}$ & $895 \mu \mathrm{L}$ &
\end{tabular}

Store for $6 \mathrm{mo}$ at $-20^{\circ} \mathrm{C}$.

NT2 Buffer

\begin{tabular}{lcr} 
Reagent & $\begin{array}{c}\text { Quantity } \\
\text { (for } 100 \mathrm{~mL})\end{array}$ & $\begin{array}{c}\text { Final } \\
\text { concentration }\end{array}$ \\
\hline Tris- $\mathrm{HCl}(1 \mathrm{M}, \mathrm{pH} 7.4)$ & $5 \mathrm{~mL}$ & $50 \mathrm{~mm}$ \\
$\mathrm{NaCl}(5 \mathrm{M})$ & $3 \mathrm{~mL}$ & $150 \mathrm{~mm}$ \\
$\mathrm{MgCl}_{2}(1 \mathrm{M})$ & $0.1 \mathrm{~mL}$ & $1 \mathrm{~mm}$ \\
$\mathrm{Nonidet} \mathrm{P-40} \mathrm{(NP-40;10 \% )}$ & $0.5 \mathrm{~mL}$ & $0.05 \%$ \\
$\mathrm{H}_{2} \mathrm{O}$ & $91.4 \mathrm{~mL}$ &
\end{tabular}

Store for 6 mo at $4^{\circ} \mathrm{C}$.

Proteinase $K$ Buffer for SELEX (2×)

\begin{tabular}{lcc} 
Reagent & $\begin{array}{c}\text { Quantity } \\
\text { (for } 50 \mathrm{~mL})\end{array}$ & $\begin{array}{c}\text { Final } \\
\text { concentration }\end{array}$ \\
\hline SDS $(10 \%)$ & $2.5 \mathrm{~mL}$ & $0.5 \%$ \\
EDTA $(0.5 \mathrm{M}, \mathrm{pH} 8.0)$ & $0.4 \mathrm{~mL}$ & $4 \mathrm{~mm}$ \\
$\mathrm{H}_{2} \mathrm{O}$ & $47.1 \mathrm{~mL}$ &
\end{tabular}

Store indefinitely at room temperature.

Reverse Transcriptase Buffer for SELEX (10×)

\begin{tabular}{|c|c|c|}
\hline Reagent & $\begin{array}{l}\text { Quantity } \\
\text { (for } 1 \mathrm{~mL} \text { ) }\end{array}$ & $\begin{array}{c}\text { Final } \\
\text { concentration }\end{array}$ \\
\hline Tris-HCl (1 м, pH 8.3) & $500 \mu \mathrm{L}$ & $500 \mathrm{~mm}$ \\
\hline $\mathrm{KCl}(2 \mathrm{M})$ & $200 \mu \mathrm{L}$ & $400 \mathrm{~mm}$ \\
\hline $\mathrm{MgCl}_{2}(1 \mathrm{M})$ & $60 \mu \mathrm{L}$ & $60 \mathrm{~mm}$ \\
\hline DTT (dithiothreitol; $1 \mathrm{M}$ ) & $10 \mu \mathrm{L}$ & $10 \mathrm{~mm}$ \\
\hline $\mathrm{H}_{2} \mathrm{O}$ & $230 \mu \mathrm{L}$ & \\
\hline
\end{tabular}

Store for $6 \mathrm{mo}$ at $-20^{\circ} \mathrm{C}$.

SDS Extraction Buffer

\begin{tabular}{lcr} 
Reagent & $\begin{array}{c}\text { Quantity } \\
\text { (for } 500 \mathrm{~mL})\end{array}$ & $\begin{array}{c}\text { Final } \\
\text { concentration }\end{array}$ \\
\hline Tris- $\mathrm{HCl}(1 \mathrm{M}, \mathrm{pH} 7.5)$ & $10 \mathrm{~mL}$ & $20 \mathrm{~mm}$ \\
EDTA $(0.5 \mathrm{M}, \mathrm{pH} 8.0)$ & $1 \mathrm{~mL}$ & $1 \mathrm{~mm}$ \\
$\mathrm{SDS}(10 \% \mathrm{w} / \mathrm{v})$ & $25 \mathrm{~mL}$ & $0.5 \%(\mathrm{w} / \mathrm{v})$ \\
$\mathrm{H}_{2} \mathrm{O}$ & $464 \mathrm{~mL}$ & -
\end{tabular}

Store indefinitely at room temperature. 
SELEX to Identify Protein-Binding Sites on RNA

T7 Transcription Buffer (10×)

\begin{tabular}{lcc} 
Reagent & $\begin{array}{c}\text { Quantity } \\
\text { (for } 1 \mathrm{~mL})\end{array}$ & $\begin{array}{c}\text { Final } \\
\text { concentration }\end{array}$ \\
\hline Tris- $\mathrm{HCl}(1 \mathrm{M}, \mathrm{pH} 8.0)$ & $400 \mu \mathrm{L}$ & $400 \mathrm{~mm}$ \\
$\mathrm{MgCl}_{2}(1 \mathrm{M})$ & $200 \mu \mathrm{L}$ & $200 \mathrm{~mm}$ \\
$\mathrm{DTT}$ (dithiothreitol; 1 M) & $50 \mu \mathrm{L}$ & $50 \mathrm{~mm}$ \\
$\mathrm{H}_{2} \mathrm{O}$ & $350 \mu \mathrm{L}$ &
\end{tabular}

Store for $6 \mathrm{mo}$ at $-20^{\circ} \mathrm{C}$.

\section{REFERENCES}

Bouvet P. 2001. Determination of nucleic acid recognition sequences by SELEX. Methods Mol Biol 148: 603-610.
Kenan DJ, Keene JD. 1999. In vitro selection of aptamers from RNA libraries. Methods Mol Biol 118: 217-231. 


\section{SELEX to Identify Protein-Binding Sites on RNA}

James L. Manley

Cold Spring Harb Protoc; doi: 10.1101/pdb.prot072934

\begin{tabular}{rc}
\hline $\begin{array}{r}\text { Email Alerting } \\
\text { Service }\end{array}$ & Receive free email alerts when new articles cite this article - click here. \\
\hline $\begin{array}{c}\text { Subject } \\
\text { Categories }\end{array}$ & Browse articles on similar topics from Cold Spring Harbor Protocols. \\
& $\begin{array}{c}\text { Molecular Biology, general (1293 articles) } \\
\text { Protein Expression and Interactions (93 articles) } \\
\text { RNA (317 articles) } \\
\text { RNA, general (269 articles) } \\
\text { RT-PCR (49 articles) }\end{array}$ \\
\hline
\end{tabular}

